\title{
İmkb'ye Kote Edilmiş Havayolu Taşimaciliği Sektöründe Trend Analizine İlişkin Örnek Bir Uygulama
}

\author{
Fatma AKCANLI* \\ Mustafa SOBA* \\ Ali KESTANE ${ }^{* * *+}$
}

\section{Özet}

Hizmet sektöründe yaşanan hızlı gelişmeler, son yıllarda havayolu taşımacıllı̆̆ sektöründe de etkisini göstermektedir. Globalleşmenin, gelişen teknoloji ve hemen hemen her sektörde büyük önem kazanan rekabet avantajının etkisi ile havayolu ulaşımı önemli hale gelmiştir. Sektörde yaşanan değişim ve gelişim nedeniyle, havayolu işletmelerinin bu gelişmeler karşısında kendilerine en uygun vizyonu oluşturmaları, onlara önemli ölçüde rekabet avantajı kazandırmaktadır. Stratejik bir coğrafyaya sahip olan Türkiye'de havayolu taşımacılığının faaliyet oranı düşük düzeydedir. $\mathrm{Bu}$ durumun nedeni olarak yolcu taşımacilığının karayolu taşımacılı̆̆ 1 ile gerçekleşmesi gösterilebilir. Ancak karayolu taşımacılığındaki zaman israfı, ulaşım problemi, artan yol trafiğinden kaynaklanan çevre kirliliği gibi konularda havayolu taşımacılığı daha avantajlı ve güven arz etmektedir. Küresel ekonominin de etkisiyle oluşan uluslararası pazarlara ulaşma konusunda hem zaman açısından hem de rekabet avantajı elde etmek açısından havayolu taşımacılığının kullanım oranı her geçen gün daha fazla önem kazanmaktadır. Havayolu taşımacılığının kullanım oranının Türkiye'de az olmasının bir başka nedeni de yasal düzenlemelerdeki yetersizliklerdir.

Bu çalışmada havayolu taşımacılığının Türkiye'deki önemi ve yeri anlatılmış olup, İstanbul Menkul Kıymetler Borsasına kayıtlı olan büyük ölçekli iki havayolu işletmesinin finansal tabloları kullanılarak, performansları Trend (Eğilim Yüzdeleri) yöntemi ile değerlendirilmiştir. Çalışmanın kapsadığı dönemler 2007-2011 yılları olarak ele alınmış olup, işletmeler açısından aralarında anlamlı ilişki kurulabilen hesap kalemleri arasında gelecekte almaları gereken önlemler ile ilgili bir değerlendirme yapılmıştır.

\footnotetext{
*Yrd. Doç.Dr., Uşak Üniversitesi,İïBF, İşletme

** Yrd. Doç.Dr., Uşak Üniversitesi, İİBF, İşletme

*** Uşak Üniversitesi Lisans Mezunu, İ̈BF, İşletme
} 
Anahtar Kelimeler: Havayolu, Havayolu Taşımacılığı, Eğilim Yüzdeleri Yöntemi

\begin{abstract}
The rapid developments in the service sector in recent years, shows the effect of the air transport industry. Impact of globalization, emerging technologies, and the winner of great importance in almost every sector has become an important competitive advantage, with the effect of air transport. Change and development in the sector, due to the vision of the best airline companies establish themselves in the face of these developments, gives them a significant competitive advantage. However, Turkey, which has a strategic geography of air transport activity rate is low. Passenger transport by road transport as a cause of this condition can be shown to happen. This disparity between the passenger transport sector raises several issues. Road transport is a waste of time, transportation problems, issues such as environmental pollution caused by increased road traffic, air transport is more advantageous and security of supply. Of the impact of the global economy, both in terms of time to reach international markets, as well as to gain a competitive advantage in terms of air transport utilization rate is becoming more and more important with each passing day. Another reason for the use of air transport is less than the rate in Turkey is due to deficiencies in the legal regulations.

The importance of air transport in Turkey, and the location is described in this study, the two airlines operating in the sector of large-scale financial statements of the entity, using the percentage of performance trend (Trend) method were evaluated. In the years of 2007-2011 period covered by the study are discussed and shown in terms of a relationship between the installed sheet items made an assessment of the measures to be taken in the future.

Key Words: Airline, Air Transport, Trend Percentage Method

\section{Giriș}

Günümüzde artan nüfus oranları, büyüyen ekonomi, gelişen teknoloji ve bununla birlikte içinde bulunduğumuz global dünya şartları bir takım sorunları beraberinde getirmiştir. Yaşanılan bu sorunlar arasında ulaşım konusu büyük önem taşımaktadır.
\end{abstract}


Uşak Üniversitesi Sosyal Bilimler Dergisi

$2013,6 / 3$

F. AKCANLI, M. SOBA, A. KESTANE

Dünya ekonomisi üzerinde her geçen gün artan işletme sayısı ve bu işletmelerin mevcut müşterilerine ulaşma olanağı karmaşık bir hal almıştır. Büyük coğrafyalarda faaliyet gösteren işletmelerin kullandıkları ulaşım araçları da buna göre şekillenmiştir. Artan rekabet şartları ile birlikte havayolu ulaşımı ve taşımacılığı, diğer ulaşım ve taşımacılık sektörlerine göre daha çok gelişme göstermiştir.

1980'li yıllara gelinceye kadar havayolu taşımacılığında rekabetin az olmasının nedeni yasal düzenlemelerden kaynaklanmıştır. ABD'de 1978 yılında yapılan yasal düzenlemeler ile havayolu taşımacılığında meydana gelen serbestlikle rekabet artmıştır. 11 Eylül 2001 sonrası havayolları sektöründe meydana gelen dalgalanmalardan dolayı büyük iflaslar meydana gelmiş ve kayıplar yaşanmıştır. Günümüzde ise Amerika'nın bu sektördeki payını kaybetmesinin önemli bir nedeni de; Avrupa, Ortadoğu ve Asya Pasifikten gelen rekabet ortamı karşısında gücünü koruyamamasından kaynaklanmaktadır. 1990'lı yıllardan itibaren havayolu sektöründe birleşmelerin ve satın almaların önem kazandığı görülmektedir. Mevcut havayolu taşımacılığının dünya üzerindeki dağılımını \%54'lük pay ile Avrupa ilk sırada oluşturmaktadır. Asya-Pasifik ülkelerinin yanı sıra Çin'in yüksek ihracat rakamlarına ulaşması nedeniyle \%43'lük payla ikinci sırada yer almakta olup bunu Orta Doğu ülkeleri takip etmektedir (Ertürk, 2011: 2$3)$.

\section{TÜRKIYYE' DE HAVAYOLU TAŞIMACILIĞI}

Büyük bir coğrafya üzerinde yer alan Türkiye, kıtalar arasında köprü konumunda olması nedeni ile ulusal ve uluslararası havayolu taşımacılığı ve ulaşımında stratejik bir özelliğe sahiptir. Türkiye'nin havayolu taşımacılığında tarihsel gelişimine bakıldığı zaman ilk çalışmalar Osmanlı Dönemi'nde askeri alanda meydana gelmiştir. İlk sivil havacılık çalışmaları ise 1912 yılında İstanbul'da Atatürk Hava Limanı'nın yakınında bulunan Sefaköy'de başlanmıştır. Türk Hava Kurumu'nun temelleri 1925 yılında atılmıştır. Türkiye'de sivil havacılık hususunda en önemli gelişmeler İkinci Dünya Savaşı'ndan sonra meydana gelmiştir. Bu dönemlerde modern uçaklar geliştirilerek havalimanlarının yapımına büyük önem verilmiştir. Devlet Havacılık Meydanları İşletmesi 1956 yılında oluşturulan bir yasal düzenleme ile kurulmuş olup, havalimanlarının işletilmesi ve uçuş güvenliğinin sağlanması bu kuruma bırakılmıştır. 1980'li yıllardan itibaren bu sektörde önemli gelişmeler meydana gelmiştir. Daha sonraları Türk Hava Yolları'nın (THY) modernize yapısı oluşturularak filosu geliştirilmeye başlanmış ve hizmet kalitesi ile güvencesi artırılarak hem iç hatlarda hem de uluslararası hatlarda ekonomik açıdan büyük önem kazandığ gözlemlenmiştir. Bu çalışmalar ile birlikte özel havayolu taşımacılığı önemli 
hale gelmiştir (MEB, 2011:5). Türkiye'de şu anda toplam ihracatının \%8'lik kısmı bu sektörden karşılanmaktadır.

Artan ve giderek daha karmaşık bir hal alan rekabet ortamında havayolu işletmelerinin bu durumu göz önünde bulundurularak, mali yapılarını değerlendirebilmeleri için bazı analiz teknikleri ve yöntemler geliştirilmiştir. Bu çalışma ile Türkiye'de havayolu taşımacılığında faaliyet gösteren iki işletmenin 2007 ile 2011 yılları arasındaki finansal performansları karşılaştırılarak, Trend Analizi yöntemine göre değerlendirilmesi yapılmıştır. Her iki işletmenin de finansal durumlarındaki değişimlerin olumlu ve olumsuz yönleri ortaya konularak işletmelerin alması gereken önlemler ve kararlar hakkında bazı önerilerde bulunulmuştur.

\section{LİTERATÜR}

Türkiye'de kamu hastanelerinin 1996-2000 yılları arasındaki finansal durumu Özgülbaş tarafından yapılan bir çalışmada trend analizine göre değerlendirilmiş ve alınan sonuçlara göre, finansal gelişimlerin belirlenebileceği ve bu gelişim trendlerine uygun politikalar oluşturularak hastanelerin finansal performansının artırılabileceği ortaya konulmuştur (Özgülbaş, 2006: 139). Diğer bir araştırmada Özyürek ve Erdoğan tarafından finansal kurumların 2011 yılındaki finansal yapısı trend analizi ve diğer analiz tekniklerine göre değerlendirilmiş olup, finansal analiz yapılırken analiz tekniklerinin her birinin tek başına değil birlikte kullanıldığı zaman daha doğru sonuçlar alınabileceği belirtilmiştir (Özyürek ve Erdoğan, 2011: 235). Sarılgan, Türkiye'de bölgesel havayolu taşımacıllı̆ı̆ın geliştirilmesi için 2011 yılında yaptığı araştırmada ise yurtiçi yolcu taşımacılığında büyük dengesizliklerin olduğunu ve gerekli düzenlemelerle ulaşımda karşılaşılabilecek güçlüklerin azaltılabileceği ve havayolu taşımacılığının ulaşımı daha kolay hale getirilebileceği kanısına varılmıştır (Sarılgan, 2011: 84). Bir başka çalışmada da trend analizi yöntemine göre, Türkiye'de internet bankacılığı ürünlerinin kullanımı üzerine 26 bankanın 2006-2010 yılları verileri kullanılarak araştırma yapılmış ve internet bankacılığının zaman tasarrufu sağlaması, ucuz olması ve erişim kolaylığı sağlaması yönünden kullanımı artırabileceği gösterilmiştir (Yıldırım, 2011: 139). Çetiner ve Erdem'in 2011 yılında yaptıkları çalışmada ise, finansal piyasalarda trend analizine yardımcı olacak 3 indikatör geliştirilmiş ve trend analizi göstergelerini olumlu yönde geliştiren bu indikatörlerin yatırımcılara piyasada oluşan trendler hakkında bilgi edinebileceklerini göstermiştir (Çetiner ve Erdem, 2011: 8). Türkiye'de özel hastanelerin 1994-2005 yılları arasındaki finansal durumu yine Özgülbaş vd. tarafından trend analizine göre değerlendirilmiş olup, analiz kapsamındaki hastanelerin finansal 
göstergelerinin çok kötü olmadığı ancak bilimsel finansal yöntem teknikleri kullandıkları zaman karlılık oranlarının düzenli bir trend artışı gösterebileceği belirtilmiştir (Özgülbaş,vd, 2008:129-130). Karaçor ve Alptekin'in yaptığı çalışma ile 1980-2004 yılları arasındaki Türkiye ekonomisi istikrar politikaları trend analizi yardımıyla değerlendirilmiş ve alınan sonuçlara göre uygulanan politikaların amacına ulaşamaması ve uygulanamaması sebebiyle iktisadi istikrarın sağlanamamasının gerçekleşemediği sonucuna ulaşılmıştır (Karaçor ve Alptekin, 2006:340).

\section{TREND ANALİZI YÖNTEMI}

Gelişen dünya ekonomisi ve buna bağlı oluşan rekabet ortamında işletmelerin karar almaları ve varlıklarını devam ettirmelerinde geleceğe yönelik tahminler yapılabilmesi için bazı finansal tablolar ve oranlar kullanılmaktadır. Kullanılan bu finansal tablolar ve ölçütler işletmelerin başarılarının değerlendirilmesinde, geleceğe yönelik alınması gereken önlemler de ve kararlar da için önem arz etmektedir. Finansal tabloların değerlendirilmesi ise belirli bir sisteme bağlı olarak ve bazı geliştirilen analiz metotları kullanılarak yapılmaktadır. Kullanılan bu yöntemlerden bir tanesi de trend analizi yöntemidir.

Finansal tablolar analizinde kullanılan trend analizi yöntemi aynı zamanda eğilim yüzdeleri analizi yöntemi olarak da adlandırılmaktadır. İlk kez 1925 yılında Stephan Gilman tarafından önerilmiş ve belirli bir zamandan itibaren bu tablolarda yer alan hesap kalemlerinin trendlerine ait verilerin analiz edilmesinde kullanılmıştır (Yalkın,1981;147). Kullanılan bu analiz yöntemi işletmelerin finansal durumunun ve faaliyet sonucu getirilerinin daha iyi belirlenmesinde ve geleceğe yönelik gerçeğe daha yakın tahminler yapılmasına olanak sağlayabilmektedir (Çömlekçi,2004;201).

Eğilim yüzdeleri yöntemi, finansal tablolarda bulunan hesap kalemlerinin dönemler bazında göstermiş oldukları eğilimlerin incelenmesinde yararlanılan dinamik bir analiz metodudur. Bu metot birbirini takip eden dönemler arasındaki finansal tablolara ait hesap kalemlerinin baz (temel) alınmasıyla mali tablolara göre göstermiş olduğu artış ve azalışlar yüzde olarak hesaplanmasıyla oluşmaktadır. Baz (temel) alınan yıla göre hesaplanmış olan yüzdeler, belirli dönemler arasındaki finansal durumun olumlu ve olumsuz yönleriyle ilgili gelişmeleri hakkında bilgi sağlamaktadır (Gülcan,2011;60).

Finansal tabloların analizinde kullanılmakta olan bu yöntem, herhangi bir y1l baz (temel) yıl olarak seçilir ve o yıla ait hesap kalemleri 100 olarak kabul edilir. İzleyen yıllardaki aynı türden değerler baz (temel) yıla bölünerek yüzde olarak değişimler hesaplanır (Bayazıtlı,2002;1). 
Mali tablolardaki her hesap kaleminin eğilim yüzdesi şu şekilde hesaplanir:

\section{- Baz Yıla Göre Eğilim Yüzdesi Hesaplama;}

Trend Yüzdesi $=\frac{\text { Hesap kalemlerinin diğer yıllardaki mutlak değeri }\left(x y_{1} l_{1}\right)}{\text { Hesap kalemlerinin baz yılındaki mutlak değeri }} \times 100(1)$

Eğilim yüzdelerinin hesaplanışı esnasında, baz (temel) alınan yıldaki mutlak değeri olmayan bir hesap kaleminin diğer yıllar için trend yüzdesi de olmaz. Eğilimlerin karşılaştırılmasında, her bir hesap kaleminin göstermiş olduğu eğilimin belirlenmesi ve farklılıkların ortaya konulması gerekmektedir (Kurnaz,2008; 6).

- Önceki Yıla Göre Eğilim Yüzdesi Hesaplama;

$$
\text { Trend Yüzdesi }=\frac{\text { Hesap kaeminin } x y_{1} l_{1} \text { ndaki tutar } 1}{\text { Hesap kaleminin önceki } y_{1} l_{\text {daki }}(x-1) \text { tutar }_{1}} \times 100
$$

Her yılın finansal tablosuna ait olan kalemler bir önceki yılın hesap kalemlerine göre hesaplanarak eğilim yüzdesi belirlenir.

Bir hesap kaleminin baz (temel) yıla ait rakamı yoksa bir sayının sıfıra bölünmesi sonsuz çıkacağından o hesap kalemin yıllara ilişkin olarak eğilim yüzdesi hesaplanamamaktadır (Kirac1,2012).

Finansal tablolardaki tek bir hesap kalemi gerekli bilgileri tam olarak veremeyeceğinden asıl amaç birbirleriyle uyumlu olan hesap kalemlerini karşılaştırılarak analiz edilmesi ve işletmenin faaliyetleri ile ilgili sonuçların verimli bir şekilde değerlendirilebilmesidir (Güngörmüş, 2007: 2).

Trend yüzdeleri zaman içerisinde hesap kalemlerinin değerlerini ayrıntılı şekilde yansıttı̆̆ 1 için daha ayrıntılı analizlerin yapılmasına da kaynak teşkil etmektedirler. Trend analizinde bazı hesap kalemleri arasında ilişki karşılaştırılarak gelişmeler takip edilebilmektedir. İlişkilendirilebilecek bazı hesap kalemleri Tablo 1'de verilmiştir. 
Uşak Üniversitesi Sosyal Bilimler Dergisi

$2013,6 / 3$

F. AKCANLI, M. SOBA, A. KESTANE

Tablo 1: Trend Analizinde Kullanılan Birbirleriyle İlişkili Hesap Kalemleri

\begin{tabular}{|l|l|}
\hline Hazır Değerler & Kisa Vadeli Kaynak \\
\hline Stok & Net Satışlar İlişkisi \\
\hline $\begin{array}{l}\text { Kısa Vadeli Yabancı } \\
\text { Kaynaklar }\end{array}$ & $\begin{array}{l}\text { Dönen Varlıklar } \\
\text { İlişkisi }\end{array}$ \\
\hline Stoklar & Ticari Borçlar \\
\hline Dönen Varlıklar & Net Satışlar \\
\hline Yabancı Kaynaklar & Öz kaynaklar \\
\hline Maddi Duran Varlıklar & Net Satışlar \\
\hline Brüt Satışlar & Faaliyet Giderleri \\
\hline
\end{tabular}

Trend analizinde bilanço ve gelir tablosunun kalemleri ayrı ayrı hesaplanabildiği gibi birlikte de hesaplanabilmektedir. İşletmenin faaliyet sonuçlarının olumlu bir şekilde analiz edilebilmesi, bilançoda bulunan bir hesap kalemiyle gelir tablosunda bulunan bir hesap kaleminin birlikte incelenmesi ile mümkün olabilmektedir. Bu şekilde yapılan bir analiz ile daha somut ve gerçekçi bilgiler sağlanabilmektedir. Bilançoda olduğu gibi gelir tablosunda da baz (temel) alınan yıl her açıdan normal bir yıl olmalıdır. Ancak bu şekilde gelir tablosunda yer alan hesap kalemlerindeki meydana gelen artış ve azalışlar objektif bir şekilde değerlendirilebilinmekte ve bu değişimler baz (temel) yıla oranlanarak önlemler ve kararlar alınarak işletmenin geleceğine yön verilebilmektedir (Bayazıtll,2002;3-6).

\section{TÜRK HAVA YOLLARI A.Ş.'NIN VE ÇELEBİ HAVAYOLU SERVISI'NIN 2007-2011 YILLARI ITTIBARIYYLE TREND ANLAİII İLE INNCELENMESI}

Türkiye'de ulaşım sektöründe faaliyet gösteren ve IMKB'ye kote olmuş Türk Hava Yolları ve Çelebi Havayolu Servisi'nin 2007-2011 yılları arasındaki finansal bilanço ve gelir tablosundaki verilerinden yararlanarak 9 ayrı hesap kaleminin ikili olarak birbirleriyle ilişkileri karşılaştırmalı olarak değerlendirilmiştir. 
Uşak Üniversitesi Sosyal Bilimler Dergisi

$2013,6 / 3$

F. AKCANLI, M. SOBA, A. KESTANE

Tablo 2: Türk Hava Yolları ve Çelebi Havayolu Servisi'nin 20072011 Yılları Arasındaki Eğilim Yüzdeleri Yöntemi İle Stok-Net Satış İlişkisi

\begin{tabular}{|l|l|l|l|l|l|l|l|l|l|}
\hline \multicolumn{10}{|c|}{ STOK VE NET SATIŞ İLIŞKISI } \\
\hline \multicolumn{2}{|l|}{ Türk Hava Yolları } \\
\hline & 2007 & 2008 & 2009 & 2010 & 2011 & 2008 & 2009 & 2010 & 2011 \\
\hline Stoklar & 100 & 85,01 & 128,77 & 148,71 & 217,6 & 101,38 & 85,8 & 102,77 & 145,86 \\
\hline Net Satış & 100 & 128,30 & 147,42 & 176,48 & 247,57 & 109,29 & 112,59 & 125,59 & 171,1 \\
\hline
\end{tabular}

Tablo 2'de görüldügü gibi, Türk Hava Yolları'nın stokları da net satışları da söz konusu dönemlerde artış eğilimi göstermiştir. Bu artış yıllar itibariyle artan bir eğilim göstermiştir. Aynı hesap kalemleri arasındaki ilişki Çelebi Havayolu Servisi için değerlendirildiğinde; stokların 2009 yılı dışında artış eğilimi gösterdiği gözlemlenmiştir. Her iki işletme için de net satışlar y1llar itibariyle düzenli olarak artış göstermiştir. Stoklar ve net satışlar 2011 yılında artış hızı her iki işletme için de bir önceki yıla göre daha fazla düzeyde gerçekleşmiştir. Satışların yıllar itibariyle düzenli olarak artışı stokların satılabildiği anlamına gelirken, bu durum stokların satışlarla eritilebilmesi, Türk Hava Yolları'nın ve Çelebi Havayolu Servisi'nin iyi bir stoklama politikası izleyebilmesinin ve stokların bozulma-demode olma gibi bir risk olmadan satılabildiğinin göstergesidir.

Tablo 3: Türk Hava Yolları ve Çelebi Havayolu Servisi'nin 20072011 Yılları Arasındaki Eğilim Yüzdeleri Yöntemi ile Ticari Alacak-Net Satış İlişkisi

\begin{tabular}{|l|l|l|l|l|l|l|l|l|l|}
\hline \multicolumn{10}{|c|}{ TICARI ALACAK VE NET SATIŞ İLIŞKİSI } \\
\hline Türk Hava Yolları & 2007 & 2008 & 2009 & 2010 & 2011 & 2008 & 2009 & 2010 & 2011 \\
\hline & 100 & 142,31 & 181,54 & 235,44 & 309,94 & 92,92 & 122,22 & 146,74 & 191,86 \\
\hline Ticari Alacak & 100 & 128,30 & 147,42 & 176,48 & 247,57 & 109,29 & 112,59 & 125,59 & 171,1 \\
\hline Net Satış & & & & & & & & & \\
\hline
\end{tabular}

Tablo 3'de görüldüğg̈ gibi, Ticari Alacaklar ve Net Satış hesap kalemlerinin ele alınan yıllar içinde her iki şirkette de artış eğiliminde olduğu gözlenmiştir. Ancak, Türk Hava Yolları işletmesinde Ticari Alacaklar yıllar itibariyle değerlendirildiğinde Net Satışlara göre daha fazla artış eğilimi içerisinde olduğu görülmüştür. Bu durum THY'nin alacaklarını tahsilde güçlük çekebileceğini ve fon gereksiniminin olabileceği anlamına gelmektedir. İşletmenin dışarıdan fon sağlamaya yöneldiği durumlarda ise borç yükünün artabileceği söylenebilir. Aynı durum Çelebi Havayolu 
Servisi tarafından değerlendirildiğinde; yıllar itibariyle Ticari alacakların artış hızının net satışlarınkinden yüksek olduğu gözlenmiştir. Ancak bu artış 2008 yılında Net satışlarının Ticari alacalarına göre fazla artış eğilimde olduğu görülmektedir. Bu durum işletmenin 2008 yılında mali durumunun iyi olduğunu ifade ederken izleyen yıllar itibariyle ticari alacakların artış hızının net satışların artış hızını geçtiği görülmektedir. Bu da işletmenin kredili satışlarda istikrarlı bir politika izleyemediği ve alacaklarını tahsil etmede güçlükler çekebileceği anlamına gelmektedir.

Tablo 4: Türk Hava Yolları ve Çelebi Havayolu Servisi'nin 20072011 Yılları Arasındaki Eğilim Yüzdeleri Yöntemi ile Stok-Ticari Borç İlişkisi

\begin{tabular}{|l|l|l|l|l|l|l|l|l|l|}
\hline \multicolumn{10}{|c|}{ STOK VE TİCARİ BORÇ İLIŞKİSI } \\
\hline Türk Hava Yolları & \multicolumn{10}{c|}{ Çelebi Havayolu Servisi } \\
\hline & 2007 & 2008 & 2009 & 2010 & 2011 & 2008 & 2009 & 2010 & 2011 \\
\hline Stoklar & 100 & 85,01 & 128,77 & 148,71 & 217,6 & 101,38 & 85,8 & 102,77 & 145,86 \\
\hline Ticari Borç & 100 & 119,91 & 154,55 & 202,8 & 276,03 & 102,39 & 132,55 & 146,7 & 165 \\
\hline
\end{tabular}

Tablo 4'te görüldüğü gibi, yıllar itibariyle THY'nin Stoklar ile Ticari Borç hesap kalemleri yıllar itibariyle sürekli artan bir eğilim göstermiştir. Bu işletmenin Ticari borçlarının artış hızı stokların artış hızından yüksek olmasına rağmen çok yüksek bir farklılık görülmemektedir. Bu durum işletmenin iyi bir stok politikasının olduğunu, kısa vadedeki kaynaklarını zamanında ödeyebildiğini ve likidite durumunun iyi olduğunu göstermektedir. Ticari borçlar ve stoklardaki bu artış eğilimi Çelebi Havayolu Servisi için de yıllar itibariyle artarak devam ettiği, ancak işletmenin 2009 yılındaki stok miktarında bir önceki yıla göre düştüğü gözlenmiştir. Buna rağmen işletmenin Ticari Borçları artan bir eğilim sergilemiştir. Bu durum işletmenin 2009 yılında geçmiş borçlarının ödenmeden yeniden borçlandığı ve borçlarını ödeyemediği anlamına gelmektedir. Ancak işletmenin mali yapısının 2009 yılı dışında stok artış hızı ve Ticari borçların artış hızı incelendiğinde genel olarak olumlu olduğu sonucuna ulaşılmıştır. 
Uşak Üniversitesi Sosyal Bilimler Dergisi

$2013,6 / 3$

F. AKCANLI, M. SOBA, A. KESTANE

Tablo 5: Türk Hava Yolları ve Çelebi Havayolu Servisi'nin 20072011 Yılları Arasındaki Eğilim Yüzdeleri Yöntemi ile Dönen Varlık-Net Satış İlişkisi

\begin{tabular}{|l|l|l|l|l|l|l|l|l|l|}
\hline \multicolumn{10}{|c|}{ DÖNEN VARLIK VE NET SATIŞ İLIŞKİsi } \\
\hline \multicolumn{10}{|c|}{ Türk Hava Yolları } \\
\hline & 2007 & 2008 & 2009 & 2010 & 2011 & 2008 & 2009 & 2010 & 2011 \\
\hline & & & & & & & & & \\
\hline Dönen Varlık & 100 & 173,49 & 188,22 & 234,74 & 273,85 & 155,52 & 195,66 & 163,06 & 276,15 \\
\hline Net Satış & 100 & 128,30 & 147,42 & 176,48 & 247,57 & 109,29 & 112,59 & 125,29 & 171,1 \\
\hline
\end{tabular}

Tablo 5'e bakıldığında, ele alınan yıllar için THY'nin Dönen Varlıklar ve Net Satış hesap kalemlerindeki ilişki yıllar itibariyle sürekli artış eğilimi göstermiştir. İşletmenin dönen varlıklara göre net satışlarının daha hızlı bir artış eğilimi göstermesi, dönen varlıkların devir hızının yüksek olduğu ve borçlanmaya gerek duymayacağı anlamına gelmektedir. Bu durum THY'nin istikrarlı politikalarının karlılığını ve likidite durumunu da olumlu yönde etkileyebileceğini göstermektedir. Diğer taraftan Çelebi Havayolu Servisi'nin yıllar itibariyle durumuna bakıldığında her iki hesap kaleminin de artış eğilimi içerisinde olduğu ancak 2010 yılında dönen varlık artış hızının bir önceki yıla göre düştüğü görülmektedir.

Tablo 6: Türk Hava Yolları ve Çelebi Havayolu Servisi'nin 20072011 Yılları Arasındaki Eğilim Yüzdeleri Yöntemi ile Dönen Varlık-Kısa Vadeli Yabancı Kaynak İlişkisi

\begin{tabular}{|c|c|c|c|c|c|c|c|c|c|}
\hline \multicolumn{7}{|c|}{ DÖNEN VARLIK VE KISA VADELİ YABANCI KAYNAK İLIŞKİSİ } \\
\hline & 2007 & 2008 & 2009 & 2010 & 2011 & 2008 & 2009 & 2010 & 2011 \\
\hline & 100 & 173,49 & 188,22 & 234,74 & 273,85 & 155,52 & 195,66 & 163,06 & 276,15 \\
\hline Dönen Varlık Hava Yolları & 100 & 141,58 & 170,95 & 222,83 & 346,54 & 105,48 & 146,81 & 142,85 & 299 \\
\hline $\begin{array}{c}\text { Kısa Vadeli } \\
\text { Yabancı Kaynak }\end{array}$ & & & & & & & & & \\
\hline
\end{tabular}

Tablo 6'te görüldüğü gibi, yıllar itibariyle THY'nin dönen varlık ve kısa vadeli yabancı kaynaklarında istikrarlı bir artış olduğu gözlenmiştir. İşletmenin 2011 yılındaki kısa vadeli yabancı kaynaklarının artış hızı dönen varlıkların artış hızını geçmesi, borçlarını ödeyememe riskiyle karşı karşıya kaldığı anlamına gelmektedir. Aynı hesap kalemleri arasındaki ilişki Çelebi Havayolu Servisi açısından incelendiğinde artan bir eğilim olduğu gözlemlenmiştir. Fakat işletmenin 2010 yılında dönen varlıklarındaki artış hızları ile kısa vadeli yabancı kaynaklarının artış hızlarında bir önceki yıla göre düşüş gözlenmiştir. Ayrıca 2011 yılında kısa vadeli yabancı 
kaynaklarının artış hızı dönen varlıklarının artış hızından daha fazla olduğu görülmüştür. $\mathrm{Bu}$ anlamda işletmenin borç ödeme gücünün zayıfladı̆̆ı anlamina gelmektedir.

Tablo 7: Türk Hava Yolları ve Çelebi Havayolu Servisi'nin 20072011 Yılları Arasındaki Eğilim Yüzdeleri Yöntemi ile Maddi Duran VarlıkNet Satıș İliş̧kisi

\begin{tabular}{|l|l|l|l|l|l|l|l|l|l|}
\hline \multicolumn{10}{|c|}{ MADDi DURAN VARLIK VE NET SATIŞ İLIŞKİSİ } \\
\hline Türk Hava Yolları & 2007 & 2008 & 2009 & 2010 & 2011 & 2008 & 2009 & 2010 & 2011 \\
\hline & 100 & 156,12 & 148,75 & 199,22 & 342,96 & 94,66 & 103,5 & 149,51 & 145,91 \\
\hline Maddi Duran V. & 100 & 128,30 & 147,42 & 176,48 & 247,57 & 109,29 & 112,59 & 125,29 & 171,1 \\
\hline Net Satış & 100 &
\end{tabular}

Tablo 7'da görüldüğü gibi, Maddi Duran Varlıklar ve Net Satışların THY için ilgili dönemdeki yıllar itibariyle istikrarlı bir artış eğilimi içerisinde olduğu gözlemlenmiştir. THY'nin maddi duran varlık artış hızında 2009 yılında bir önceki yıla göre düşüş olmasına rağmen net satışlarda artış eğilimi olduğu görülmektedir. Ancak izleyen yıllara bakıldığında artan eğilim devam etse de maliyetlerin artmış olabileceği düşünülürken, 2011 yılındaki maddi duran varlıklardaki artış hızı net satışlardaki artışın üzerindedir. Çelebi Havayolu Servisi'nin y1llar itibariyle hesap kalemlerindeki artışlar istikrarlı bir şekilde devam etmiştir. Ancak işletmenin 2011 yılındaki net satışların artış hızı maddi duran varlıklarının artış hızına göre bir önceki yıla kıyasla daha yüksek düzeyde gerçekleşmiştir.

Tablo 8: Türk Hava Yolları ve Çelebi Havayolu Servisi'nin 20072011 Yılları Arasındaki Eğilim Yüzdeleri Yöntemi ile Maddi Duran VarlıkÖzkaynak İlişkisi

\begin{tabular}{|l|l|l|l|l|l|l|l|l|l|}
\hline \multicolumn{10}{|c|}{ MADDİ DURAN VARLIK VE ÖZKAYNAK İLISSKISİ } \\
\hline Türk Hava Yolları \\
\hline & 2007 & 2008 & 2009 & 2010 & 2011 & 2008 & 2009 & 2010 & 2011 \\
\hline Maddi Dur. V. & 100 & 156,12 & 148,75 & 199,22 & 342,96 & 94,66 & 103,5 & 149,51 & 145,91 \\
\hline Özkaynak & 100 & 156,83 & 180,90 & 196,79 & 236,25 & 105,88 & 97,57 & 104,40 & 41,01 \\
\hline
\end{tabular}

Tablo 8'de görüldüğü gibi, THY'nin 2009 yılı hariç diğer yıllarda maddi duran varlık hızının arttığı ve özkaynak artış hızının ise tüm yıllarda arttığ1 görülmüştür. Çelebi Havayolu Servisi'nin ise hesap kalemlerine bakıldığında yıllar itibariyle istikrarsız bir eğilim içinde olduğu görülmektedir. İşletmenin hesap kalemlerine genel anlamda bakıldığında 
2008 yılı dışında maddi duran varlıklarının finansmanını özkaynaklardan karşılayamadığ gözlenmiştir. Bu durum işletmenin maliyetlerinin yüksek olabileceğini ayrıca yönetimde de zorluklar yaşanabileceğini ifade etmektedir.

Tablo 9: Türk Hava Yolları ve Çelebi Havayolu Servisi'nin 20072011 Yılları Arasındaki Eğilim Yüzdeleri Yöntemi ile Uzun Vadeli Yabancı Kaynaklar-Duran Varlıklar İlişkisi

\begin{tabular}{|l|l|l|l|l|l|l|l|l|l|}
\hline \multicolumn{10}{|c|}{ UZUN VADELI YABANCI KAYNAK VE DURAN VARLIK İLIŞKİSI } \\
\hline Türk Hava Yolları \\
\hline & 2007 & 2008 & 2009 & 2010 & 2011 & 2008 & 2009 & 2010 & 2011 \\
\hline $\begin{array}{l}\text { Uzun Vadeli } \\
\text { Yab. Kay. }\end{array}$ & 100 & 174,23 & 169,29 & 805,20 & 423,74 & 110,51 & 176,49 & 213,43 & 451,79 \\
\hline Duran Varlık & 100 & 154,06 & 168,08 & 208,40 & 359,07 & 86,64 & 103,47 & 135,22 & 188,53 \\
\hline
\end{tabular}

Tablo 9'de görüldüğü üzere, yıllar itibariyle Türk Hava Yolları'nın duran varlıklarında sürekli bir artış görülmesine karşılık uzun vadeli yabancı kaynaklarının artış hızı yıllara göre değişiklik göstermektedir. Ancak 2010 yılındaki uzun vadeli yabancı kaynakların artış hızı, duran varlıkların artışının çok üzerinde bir eğilim göstermiştir. Bu durum işletmenin uzun vadeli yabancı kaynaklarının ödeme güçlüğü çekebileceğini göstermektedir. Fakat 2011 yılındaki duran varlıklarının artış hızının diğer yıllara göre yüksekliği ve uzun vadeli borç artış hızının düşüş eğiliminde olması, işletmenin uzun vadeli borç ödeyebilme kapasitesinin mümkün olabileceğini ifade etmektedir. Aynı hesap kalemleri arasındaki ilişki Çelebi Havayolu Servisi için değerlendirildiğinde; uzun vadeli yabancı kaynakların artış hızının yıllar itibariyle duran varlıkların artış hızının çok üzerindedir. $\mathrm{Bu}$ durum işletmenin uzun vadeli yabancı kaynaklarını ödeyememe durumuyla karşı karşıya kalabileceği anlamına gelmekte ve likidite sorunu yaşayabileceğin göstergesidir. 
Tablo 10: Türk Hava Yolları ve Çelebi Havayolu Servisi'nin 20072011 Yılları Arasındaki Eğilim Yüzdeleri Yöntemi ile Yabancı Kaynak-Öz kaynak İlişkisi

\begin{tabular}{|l|l|l|l|l|l|l|l|l|l|}
\hline \multicolumn{10}{|c|}{ YABANCI KAYNAKLAR VE ÖZKAYNAKLAR İLiŞKİ்́ } \\
\hline Türk Hava Yolları & 2007 & 2008 & 2009 & 2010 & 2011 & 2008 & 2009 & 2010 & 2011 \\
\hline & 100 & 161,89 & 169,92 & 228,72 & 394,57 & 108,21 & 162,96 & 181,26 & 382 \\
\hline Yabancı Kaynak & 100 & 156,83 & 180,90 & 196,79 & 236,25 & 105,88 & 97,57 & 104,40 & 41,01 \\
\hline Özkaynak &
\end{tabular}

Tablo 10'a bakıldığında, ele alınan yıllar itibariyle Türk Hava Yolları'nın yabancı kaynaklarındaki artış hızı, özkaynaklarının üzerinde bir artış eğilimi göstermiştir. Diğer yandan Çelebi Havayolu Servisi'nin yıllar itibariyle yabancı kaynaklarına bakıldığında sürekli artış eğilimi içerisinde olduğu fakat özkaynak artış hızında bir düzensizlik olduğu gözlemlenmiştir. Yabancı kaynakların sürekli artış eğilimine karşın özkaynakların düzensiz bir seyir halinde olması işletmenin aktiflerinin finansmanında yabancı kaynakların çok büyük oranla kullanıldığı anlamına gelmektedir. Bu durum 2011 yılına bakıldığında açıkça görülmektedir.

\section{SONUÇ}

Havayolu ulaşımında son yıllarda yaşanılan gelişmeler sektörde rekabetin artmasıyla ve bu rekabet ortamında karlı olarak faaliyetlerinin sürdürülebilmesi açısından önemlidir.

Çalışmada havayolu işletmelerinin 2007-2011 yılları itibariyle trend analizi yapılarak işletmelerin finansal performanslarının mali tablolar aracılığıyla belli hesap kalemleri arasındaki ilişki değerlendirilmiştir. Çalışmanın örnek kütlesinde yer alan belli hesap kalemleri stok-net satış ilişkisi, ticari alacak-net satış ilişkisi, stok-ticari borç ilişkisi, dönen varlık-net satış ilişkisi, dönen varlık-kısa vadeli yabancı kaynak borç ilişkisi, maddi duran varlık-net satış ilişkisi, maddi duran varlık-özkaynak ilişkisi, uzun vadeli yabancı kaynak-duran varlık ilişkisi, yabancı kaynak-özkaynak ilişkisi olarak oluşturulmuştur.

Türk Hava Yolları ile Çelebi Hava Servisinin 2007-2011 yılları arasındaki finansal durumu Trend analizi yöntemiyle değerlendirilmesi yapıldığında Tablo 11 oluşturulur. 
Uşak Üniversitesi Sosyal Bilimler Dergisi

$2013,6 / 3$

F. AKCANLI, M. SOBA, A. KESTANE

Tablo 11: Türk Hava Yolları ve Çelebi Hava Servisinin 2007-2011 Yılları Arasındaki Bazı Hesap Kalemleri ile Trend Analizi

\begin{tabular}{|c|c|c|c|c|c|c|c|c|c|}
\hline \multicolumn{6}{|c|}{ TÜRK HAVA YOLLARI } & \multirow{2}{*}{\multicolumn{4}{|c|}{$\begin{array}{c}\text { ÇELEBİ HAVAYOLU } \\
\text { SERVİSİ } \\
\text { YILLAR }\end{array}$}} \\
\hline \multirow{2}{*}{$\begin{array}{c}\text { HESAP } \\
\text { KALEMLERİ }\end{array}$} & \multicolumn{5}{|c|}{ YILLAR } & & & & \\
\hline & 2007 & 2008 & 2009 & 2010 & 2011 & 2008 & 2009 & 2010 & 2011 \\
\hline STOK & 100 & 85,01 & 128,77 & 148,71 & 217,6 & 101,38 & 85,8 & 102,77 & 145,86 \\
\hline NET SATIŞ & 100 & 128,30 & 147,42 & 176,48 & 247,57 & 109,29 & 112,59 & 125,59 & 171,1 \\
\hline TİCARI ALACAK & 100 & 142,31 & 181,54 & 235,44 & 309,94 & 92,92 & 122,22 & 146,74 & 191,86 \\
\hline TİCARİ BORÇ & 100 & 119,91 & 154,55 & 202,8 & 276,03 & 102,39 & 132,55 & 146,7 & 165 \\
\hline DÖNEN VARLIK & 100 & 173,49 & 188,22 & 234,74 & 273,85 & 155,52 & 195,66 & 163,06 & 276,15 \\
\hline $\begin{array}{l}\text { KISA VAD. YAB. } \\
\text { KAY. }\end{array}$ & 100 & 141,58 & 170,95 & 222,83 & 346,54 & 105,48 & 146,81 & 142,85 & 299 \\
\hline $\begin{array}{l}\text { MADDİ DURAN } \\
\text { VAR. }\end{array}$ & 100 & 156,12 & 148,75 & 199,22 & 342,96 & 94,66 & 103,5 & 149,51 & 145,91 \\
\hline $\begin{array}{l}\text { UZUN VAD. YAB. } \\
\text { KAY. }\end{array}$ & 100 & 174,23 & 169,29 & 805,20 & 423,74 & 110,51 & 176,49 & 213,43 & 451,79 \\
\hline $\begin{array}{l}\text { DURAN VARLIK } \\
\text { TOP }\end{array}$ & 100 & 154,06 & 168,08 & 208,40 & 359,07 & 86,64 & 103,47 & 135,22 & 188,53 \\
\hline $\begin{array}{l}\text { YABANCI } \\
\text { KAYNAK TOP }\end{array}$ & 100 & 161,89 & 169,92 & 228,72 & 394,57 & 108,21 & 162,96 & 181,26 & 382 \\
\hline ÖZKAYNAK & 100 & 156,83 & 180,90 & 196,79 & 236,25 & 105,88 & 97,57 & 104,40 & 41,01 \\
\hline
\end{tabular}

Tablo 11'de görüldü gibi sözkonusu yıllar içerisinde stok hesap kalemin Türk Hava Yollarında 2011 yılına kadar artış eğilimi göstermesine rağmen, Çelebi Havayolu Servisinde 2009 yılında bir düşüş eğilimi gösterip izleyen yılarda tekrar artış eğilimi içerisine girmiştir. Çelebi Havayolu Servisinde Dönen Varlık hesap kalemi ile Kısa Vadeli Yabancı Kaynak hesap kaleminin 2010 yılında bir önceki yıla göre düşüş gösterip izleyen yılda tekrar artış eğilimine girdiği görülmüştür. Çelebi Hava Yolu Servisinin Maddi Duran Varlık Hesap kaleminde ise 2011 yllında az da olsa bir düşüklük söz konuşudur. Söz konusu işletmenin Özkaynak hesap kaleminde de 2009 yılı ve 2011 yılında bir düşüş gözlemlenmiştir. Türk Hava Yollarında Maddi Duran Varlıklar ile Uzun Vadeli Yabancı Kaynak hesap kaleminin 2009 yllında bir önceki yıla göre düştügü görülmüştür. Uzun Vadeli Yabancı Kaynaklardaki söz konusu düşme 2011 yılında da tekrarlandığ1 gözlemlenmiştir. 
Uşak Üniversitesi Sosyal Bilimler Dergisi

$2013,6 / 3$

F. AKCANLI, M. SOBA, A. KESTANE

Tablo 12. Türk Hava Yolları ve Çelebi Hava Servisinin 2010-2011 Yıllarındaki Hesap Kalemlerindeki Artış Oranları

\begin{tabular}{|c|l|l|}
\hline \multicolumn{3}{|c|}{$2010-2011$ Hesap Kalemlerinin Artış Oranları (\%) } \\
\hline & THY & ÇELEBI \\
\hline STOK & 1,46 & 1,42 \\
\hline NET SATIŞ & 1,40 & 1,36 \\
\hline TICARI ALACAK & 1,31 & 1,30 \\
\hline TİCARI BORÇ & 1,36 & 1,12 \\
\hline DÖNEN VARLIKLAR & 1,16 & 1,69 \\
\hline KISA VADELİ YAB. KAY. & 1,55 & 2,09 \\
\hline MAD. DURAN VARLIK & 1,72 & 0,97 \\
\hline UZUN VADELI YAB. KAY. & 0,52 & 2,11 \\
\hline DURAN VARLIK & 1,72 & 1,39 \\
\hline YABANCI KAYNAK & 1,72 & 2,10 \\
\hline ÖZKAYNAK & 1,20 & 0,39 \\
\hline
\end{tabular}

Tablo 12'de görüldüğü gibi Stoklar ve Net Satışlar kalemi Çelebi'ye göre THY'de 0.04'lük bir artış göstermiştir. Bu artış ticari alacaklarda Çelebi Havayoluna göre 0.01, maddi duran varlıklarda 0.75, duran varlıklarda 0.33, özkaynaklarda 0.81, ticari borçlar ise 0.24 olarak gerçekleşmiştir. THY Çelebiye göre; dönen varlıklar 0.53 , kısa vadeli yabancı kaynak 0.44 , uzun vadeli yabancı kaynak 1.59, toplam yabancı kaynaklar 0.38 oraninda azalmıştır.

Çalışmanın sonucu olarak 2010-2011 yıllarındaki 11 adet hesap kalemi incelendiğinde THY'nin 2011 yılındaki uzun vadeli yabancı kaynaklarındaki artış hızı bir önceki yıla göre \%48 oranında gerilemiştir. Diğer 10 hesap kalemindeki artış oranları en düşük olarak \%20 (özkaynak) ile en yüksek \%72 oran (maddi duran varlıklarda) olarak gerçekleşmiştir.

Çelebi havayollarında ise 2011 yılındaki maddi duran varlık artış hızı \%3, özkaynaklardaki artış hızı ise \%61 oranında gerilemiştir. Diğer 9 hesap kaleminde ise \%12 (ticari borç) ile \%111 (Uzun Vadeli Yabancı Kaynak) arasında değişken oranlarda artış göstermiştir. 
Uşak Üniversitesi Sosyal Bilimler Dergisi

$2013,6 / 3$

F. AKCANLI, M. SOBA, A. KESTANE

\section{Kaynakça}

Bayazıtll,E.(2002)."Mali Analiz Teknikleri Trend Yüzdeleri Tekniği", Ankara Üniversitesi, Sosyal Bilimler Enstitüsü İşletme Anabilim Dalı Yüksek Lisans Programı,Ankara.

Çetiner,E. ve Erdem,O.A., (2011), “Finansal Piyasalarda Trend Analizine Yardımcı Olacak İndikatörlerin Geliştirilmesi", Bilişim Teknolojileri Dergisi, Cilt: 4, Sayı: 2, Bilişim Anabilim Dalı, Gazi Üniversitesi

Çömlekçi,F.(2004)."Muhasabe Denetimi Ve Mali Analiz"Anadolu Üniversitesi,Eskişehir.

Ertürk,H.(2011), “Havayolu Ekonomisi”, Devlet Hazine Müsteşarlığ1

Gülcan, N.(2011)." Finansal Oranlar Yardımıyla İşletmelerin Finansal Başarısızlıklarının Tespit Edilmesi; İMKB'de Bir Uygulama",Yüksek Lisans Tezi,Isparta.

Güngörmüş,A.H.(2007), " Emet Belediyesinde Muhasebe Bilgilerinin Finansal Analiz Teknikleri içinde Yer Alan Eğilim Yüzdeleri Yöntemi İle Bilgi Amaçlı Olarak Kullanılması", İzmir Serbest Muhasebeci Mali Müşavirler Odası Dayanışma Dergisi, No:98, Ağustos, s.27-33

Karaçor,Z. ve Alptekin,V.,(2006) “ 1980 Sonrası İstikrar Politikaları Işığında Türkiye Ekonomisinin Trend Analizi Yardımıyla Değerlendirilmesi", SÜ İ̈BF Sosyal Ve Ekonomik Araştırmalar Dergisi, cilt:6, Yı1:6, sayı:11, s:307-342

Kiracı,M.(2012)."Tren Analizi (Eğilim Yüzdeleri Analizi)",Kavram Özelliği - Hesaplanması ve Kullanımı.

Kurnaz,N.(2008)."Eğilim (Trend) Yüzdeleri Yöntemi İle Analiz", www.niyazikurnaz.net

MEB, (2011), “Ulaştırma Hizmetleri Alanı, Havayolu Taşımacıllı̆ı”, 
Uşak Üniversitesi Sosyal Bilimler Dergisi

$2013,6 / 3$

F. AKCANLI, M. SOBA, A. KESTANE

megep.meb.gov.tr/mte_program.../Hava\%20Yolu\%20Taşımacilığı.p df (erişim tarihi:11.06.2013)

Özgülbaş,N.(2006), “Türkiye'de Kamu Hastanelerinin Finansal Durum Değerlendirmede Kullanılabilecekleri Bir Yöntem: Trend Analizi", Muhasebe Ve Finansman Dergisi, Sayı: 29, $129-139$

Özgülbaş,N., Koyuncugil,A.S., Duman,R., Hatipoğlu,B.,(2008) “Özel Hastane Sektörünün Finansal Değerlendirmesi", Başkent Üniversitesi.

Özyürek,H. ve Erdoğan,E.(2011)," Finansal Kurumlarda Mali Analiz Ve Bir Uygulama", Ekonomi Bilimleri Dergisi Cilt 3, No 2, $229-238$

Sarılgan,A., (2011), “Türkiye'de Bölgesel Havayolu Taşımacılığının Geliştirilmesi İçin Yapılması Gerekenler", Anadolu University Journal of Social Science ,Cilt/Vol.: 11 - Sayı/No: 1: 69-88

Yalkın,K.Y.(1981)." İşletmelerde Mali Analiz Teknikleri", 5. baskı, S.B.F., Ankara.

Yıldırım,F., (2011), “Türkiye'de internet Bankacılı̆̆g Ürünleri Üzerine Pazar Trend Analizi", İstanbul Ticaret Üniversitesi Sosyal Bilimler Dergisi Y1l:10 Sayı:19 s.129-141 